\title{
STUDY ON CARDIAC MANIFESTATIONS AND ELECTROCARDIOGRAPHIC CHANGES IN SNAKE ENVENOMATION.
}

\section{Aravind Reddy. Gangula*}

\section{Manasa}

Post Graduate, Department Of General Medicine, Kamineni Institute Of Medical Sciences, Narketpally ,telangana. * corresponding Author

Post Graduate, Department Of General Medicine, Kamineni Institute Of Medical Sciences, Narketpally, Telangana.

ABSTRACT Snake bite is an occupational disease of farmers, plantation workers herdsmen, fishermen, snake workers and other food producers.It is therefore a medical problem that has significant implications for the nutritional and Economy of the countries. Snake envenomation is a common presentation in rural tertiary hospitals . The clinical profile of snake envenomation has been well established. However data on Electrocardiographic changes in snake envenomation particularly patients presenting to SouthIndian rural tertiary hospital are scant AIMS AND OBJECTIVES: To study on the cardiac manifestations and electrocardiographic findings of patients with snake envenomation. PLACE OF STUDY : Department of General medicine,kamineni Institute of Medical sciences, Narketpally. Duration of study- sep 2018 to sep 2020. STUDY DESIGN - Cross sectional study. SAMPLE SIZE - 60. The clinical profile of snake envenomation is varied, in its severity and type of species, hence the ECG may be cheap and simple tool to detect warning signs early to initiate timely and appropriate management .

KEYWORDS :Snake , Envenomation, ECG, Severity.

\section{BACKGROUND-}

Snake Bites is a major health problem in India. India alone contributes to about 2 lakh envenomations and 15,00020,000 deaths annually (1). There are more than 3000 species of snakes in the world. (2).

For the purpose of clinical practice, snakes are classified into poisonous (venomous) and non-poisonous (non venomous) snakes. Poisonous snakes are classified into three families and they are

- Cobra group [Elapidae]

- Viper group [Viperidae]

- Sea snake group [Hydrophidae]

"Big 4" snakes of medical importance has reflected the view that 4 species responsible for Indian snakebite mortality. They are - Indian cobra (Naja naja), Common Krait (Bungarus caeruleus),Russell's viper (Daboia russelii) and Saw scaled viper (Echis carinatus).(3) However, recently another species, the Hump-nosed pit viper (Hypnale hypnale), has been found to be capable of causing lethal envenomation, and this problem has not been recognised because of systematic misidentification of this species as the saw-scaled viper. Snakes are poikilothermic carnivorous reptiles that have evolved the venomous apparatus for the purpose of procurement of food.(4)

Most snake bites happen when the snake is trodden on, either in the dark or in undergrowth, by someone who is bare footed or wearing only sandals. The snake may be picked up, unintentionally in a handful of foliage or intentionally by someone who is trying to show off. Some bites occur when the snake (usually a krait) comes into the home at night in search of its prey (other snakes, lizards, frogs, mice) and someone sleeping on the floor rolls over onto the snake in their sleep.

Elapid bites ( cobra,Krait and coral snakes are primarily neurotoxicity. Viper bites are mainly vasculotoxic. sea snake bite are both myotoxic and neurotoxic.

Snake venom normal function is to immobilise the prey and assist in digestion. Snake venom toxic component is divided into four broad categories : enzymes, polypeptides, glycoproteins, and compounds of low molecular weight.(4) They can also be classified as protein (90-95\%) and nonprotein (5-10\%) compounds.(4). Multiple organs are effected by most snakes (5).

Due to myocardial depressant action cardiac output can be decreased. Mechanism of cardiac involvement in snake bite is not clear, it may be due to one of myriad toxins seen in snake venom which can cause enzyme alteration, morphological changes and ultra structural disturbances of myocardial tissue (6). Most snake venoms do not cross blood brain barriers. (7) Cardiotoxicity has been recognized as a feature of snake envenoming. However, it is the neuromuscular paralysis and the respiratory failure with elapid bites and the coagulation abnormalities in viperine bites, which dominate treatment efforts in patients.

Primary action of cardiotoxin is directly on cell membrane causing many effects on skeletal, cardiac, smooth muscles, nerves and neuromuscular junctions contributing to circulatory and respiratory paralysis and cardiac asystole (8). Cardiotoxin pharmacological action has been shown to be due to an irreversible depolarisation of the cell membrane transport mechanism and asystolic cardiac arrest possibly due to release of calcium from the surface membrane of myocardium.(9).

Cardiac involvement has not been fully studied earlier and so the present study is undertaken. This study is likely to contribute to the importance of assessing the cardiac status in snake envenomation.

Study procedure - This was a descriptive cross sectional study conducted by department of general medicine, Kamineni institute of Medical sciences, Narketpally, Nalgonda, Telangana. This study was conducted for 2 years from September 2018 to September 2020.

All the routine investigations aimed to evaluate the organ damage especially cardiovascular system were done including electrocardiography. A 12 lead ECG was done on the day of admission, 2nd day, and on the day of discharge with " at a paper speed $25 \mathrm{~mm} / \mathrm{sec}$. ECG was interpreted according to Schamroth.(10)

ECG changes for heart rate, rhythm disturbance (arrhythmias), ventricular ectopics, ST-T changes, conduction disturbances, evidences of electrolytic imbalance and 
myocardial ischemia/infarction were looked for

Observed data was tabulated for number of patients in abnormal and normal ECG findings, types of ECG abnormality .

\section{INCLUSION CRITERIA:}

All cases of Snake Bite coming to the hospital will be admitted and form the subjects of the study

\section{EXCLUSION CRITERIA :}

Those with existing cardiac disease, children, pregnant women, immune suppressed persons, those with any other chronic illness will be excluded from the study.

\section{METHOD OF STUDY : cross sectional}

SAMPLE SIZE: 60

\section{RESULTS AND DISCUSSION-}

A total of 60 patients with snake envenomation were included in that final study.Their clinical and electrocardiographic profiles were recorded and are presented below

Table 1 : Distribution of snake envenomation cases according to patients gender:

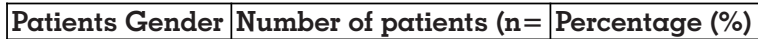

\begin{tabular}{|l|l|l|}
\hline Male & 41 & $68.3 \%$ \\
\hline
\end{tabular}

\begin{tabular}{|l|l|l|}
\hline Female & 19 & $31.6 \%$ \\
\hline
\end{tabular}

In this study, we noted that males were more frequently affected than females. Among 60 patients , 39 are males and 21 are females.

Table 2- Distribution of cases according to patients gender with in age group

\begin{tabular}{|l|l|l|l|}
\hline $\begin{array}{l}\text { Age } \\
\text { group(years) }\end{array}$ & $\begin{array}{l}\text { Number } \\
(\mathbf{n}=60)\end{array}$ & $\begin{array}{l}\text { Male } \\
(\mathbf{n}=39)\end{array}$ & $\begin{array}{l}\text { Female } \\
(\mathbf{n}=21)\end{array}$ \\
\hline$<20$ & 4 & $3(7.6 \%)$ & $1(4.76 \%)$ \\
\hline $21-30$ & 20 & $14(35.8 \%)$ & $6(28.5 \%)$ \\
\hline $31-40$ & 15 & $10(25.6 \%)$ & $5(23.8 \%)$ \\
\hline $41-50$ & 12 & $7(17.9 \%)$ & $5(23.8 \%)$ \\
\hline $51-60$ & 5 & $3(7.6 \%)$ & $2(9.5 \%)$ \\
\hline$>60$ & 4 & $2(5.1 \%)$ & $2(9.5 \%)$ \\
\hline TOTAL & 60 & 39 & 21 \\
\hline
\end{tabular}

Data from Table 2 shows that the highest prevalence of alleged snake envenomation was in the age group of 21-30 years in males $14 / 39$, the highest prevalence was in age group of 21-30 years in females 6/21 patients. Very few elderly patients presented with snake bite.

Table 3- Cardiac manifestations in patients of snake bite. \begin{tabular}{|l|l|l|}
\hline CARDIAC MANIFESTATIONS & FREQUENCY & PERCENTAGE \\
\hline
\end{tabular}

\begin{tabular}{|l|c|l|}
\hline HYPOTENSION & 7 & $11.6 \%$ \\
\hline HYPERTENSION & 9 & $15 \%$ \\
\hline BRADYCARDIA & 5 & $8.33 \%$ \\
\hline TACHYCARDIA & 15 & $25 \%$ \\
\hline PULMONARY EDEMA & 1 & $1.6 \%$ \\
\hline TACHYPNOEA & 16 & $26.6 \%$ \\
\hline
\end{tabular}

Among 60 patients, 11.6\% had Hypotension, 15\% had Hypertension $25 \%$ had tachycardia, $8.33 \%$ had bradycardia, $26.6 \%$ patients had tachypnoeic in our study.

In study done by Nayak et al, tachycardia was found in $36.7 \%$ and bradycardia in $10 \%$ of cases Hypertension in $6.7 \%$ hypotension in $16.7 \%$. (11) .In our study one patient had evidence of pulmonary edema with bilateral end inspiratory fine crepitations in both lung bases .
Table 4 - Profile of Electrocardiographic changes in patients with snake envenomation

\begin{tabular}{|l|l|l|}
\hline ECG Findings & $\begin{array}{l}\text { Number Of Patients } \\
\text { (n = 60) }\end{array}$ & Percentage (\%) \\
\hline Normal & 31 & $51.6 \%$ \\
\hline Sinus Tachycardia & 15 & $25 \%$ \\
\hline Sinus bradycardia & 5 & $8.33 \%$ \\
\hline $\begin{array}{l}\text { First degree Av } \\
\text { block }\end{array}$ & 2 & $3.33 \%$ \\
\hline $\begin{array}{l}\text { Second degree Av } \\
\text { block }\end{array}$ & 0 & $0 \%$ \\
\hline $\begin{array}{l}\text { T inversion in } \\
\text { precordial leads }\end{array}$ & 6 & $10 \%$ \\
\hline $\begin{array}{l}\text { Poor R wave } \\
\text { progression in } \\
\text { precordial leads }\end{array}$ & 2 & $3.33 \%$ \\
\hline $\begin{array}{l}\text { ST SEGMENT } \\
\text { Elevation }\end{array}$ & 3 & $5 \%$ \\
\hline $\begin{array}{l}\text { ST SEGMENT } \\
\text { Depression }\end{array}$ & 2 & $3.33 \%$ \\
\hline RBBB & 2 & $3.33 \%$ \\
\hline $\begin{array}{l}\text { ST segment } \\
\text { depression with T } \\
\text { wave inversion }\end{array}$ & 1 & $1.6 \%$ \\
\hline
\end{tabular}

The most common ECG finding was a normal sinus rhythm with normal heart rate. The most common ECG abnormality noted was Sinus Tachycardia 25\%. 8.33\% had bradycardia, $10 \%$ of patients had 'T' wave inversions. Present study was found similar to Sokolovsky. M.(12). cardiotoxicity was attributed to cardiotoxin, which also explain many of the toxic effect of cobra venom such as profound circulatory shock, with cardiovascular depression and sudden death by cardiac arrest (Banerjee RN). (13)

T wave inversion is due to coronary ischemia resulting from fall in BP and ST-T changes because of thrombosis or subintimal heamorrhage in coronary vessels. Snake venom causes disseminated intravascular coagulation which can lead to thrombosis or subintimal heamorrhage in coronary arteries and producing ECG changes. ST-T changes can be due to hypoglycemia and direct toxic effect of venom of on heart may be a likely explanation for sinus

Bradycardia, tachycardia or arrhythmia.(14)

\section{CONCLUSIONS:}

1. Snake bite is more common in the age group of $20-30 \mathrm{yrs}$ age group in this study.

The incidence is higher in males $(68.3 \%)$ than in females.

2. Cardiac involvement in snake envenomation can manifest clinically in the form of Autonomic dysfunction with hypertension, hypotension, tachycardia or bradycardia or features of heart failure.

3. Electrocardiographic changes in snake envenomation include cardiac rhythm abnormalities and features of myocardial ischemia.

4. Sinus tachycardia was the commonest ECG abnormality seen in the study.

\section{REFERENCES:}

1. Warrell DA, eds. Animal toxins. In: Manson's Tropical Disease. 20th Ed. WB Saunders, London; 1996:468-515.

2. Warrell, David A. Guidelines for the management of snake- bites.World Health organization, 2010.

3. Dutta TK, Vijeth SR. Snake bite. In: API Medicine Update. Shanker PS: 1995;5:309-12

4. Otten EJ. Venomous animal injuries. In: Rosen P, Barkin R, editors. Emergency Medicine concepts and clinical practices. New York: Mosby; 1998. pp. 924-40.

5. Norris RL, Oslund S, Auerbach PS. Disorders caused by reptile bites and marine animal envenomations. In: Fauci AS, Braunwald E, Isselbacher KJ, Wilson JD, Martin JB Kasper DL, Hauser SL, Longo DL, Harrison TR, eds. Harrison's.

6. Wu WG. Cobra cardiotoxin and phospholipase A2 as GAG- binding toxins: on the path from structure to cardiotoxicity and inflammation. Trends Cardiovasc Med 1998; 
8:270-8

7. Grenvik AKE, Ayers SM, Holbrook PR, Shoemaker WC (editors). Injuries by venomous and poisonous animals In: Textbook of Critical Care 4th ed 2000: I: 224-233.

8. Goodwin JF, Williame R, Wenger NK. Cardiomyopathy. In: Hurst J William.,editor. The Heart.4th ed. Mcgraw Hill book Co; New York: 1978. pp. 1817-1818.

9. Ahuja MMS. Progress in clinical medicine. second series. Amod-Heinemann. Publishers (India); New Delhi: 1983. pp. 136-179.

10. Schamroth L. An introduction to electrocardiography. 7th ed. Oxford: Blackwell Science

Ltd; 1990.

11. Sokolovsky M. Structure.function relationships of endothelins, sarafotoxins, and their Receptor subtypes. J Neurochemistry. 1992;59(3):809-21.

12. Nayak KC, Jain AK, Sharda DP, Mishra SN. Profile of cardiac complications of snake Bite Ind Heart J. 1990;42(3):185-8.

13. Banerjee RN. Progress in clinical medicine in India. Ahuja MMS, eds. lst ed. Arnold Heinemann Publisher, New Delhi: 1978; 21:36-179

14. Reid HA. Venomous bite and sting. 18th Ed. FLBS and Bailliers Tindal Publication, London; 1982:546. 